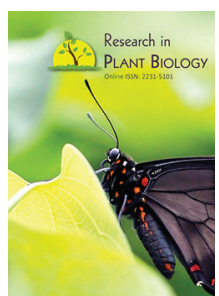

ISSN: $2231-5101$
Received: February 21, 2018

Accepted: April 30, 2018

Published: May 01, 2018

*Corresponding Author:

Shiv Shanker Gautam

Email: gautam12shiv@gmail.com

\section{Screening of antibacterial and phytochemical constituents of Malva parviflora Linn. fruit extracts against respiratory tract pathogens}

\author{
Shiv Shanker Gautam*, Navneet ${ }^{2}$, Sanjay Kumar² \\ 'Department of Microbiology, Dev Bhoomi Group of Institutions, Dehradun - 248007 Uttarakhand, India, \\ ${ }^{2}$ Department of Botany and Microbiology, Gurukul Kangri University, Haridwar -249404 Uttarakhand, India
}

\begin{abstract}
M. parviflora fruit extracts was subjected for extraction with different solvents and tested for antibacterial property by agar well diffusion method against five bacterial pathogens responsible for respiratory tract infections. From this plant, all the studied extracts revealed inhibitory action towards tested microorganisms. Highest inhibition was in methanol and ranged between $15.3 \pm 0.28$ to $20.6 \pm 0.57 \mathrm{~mm}$ with uppermost activity against $S$. pneumoniae and lowest against P. aeruginosa respectively. The MIC were fixed by two-fold serial dilution method and recorded for methanol extracts at $3.12-12.5 \mathrm{mg} / \mathrm{ml}$. Phytochemical study revealed the variable presence of secondary metabolites including alkaloids, flavonoids, glycosides, steroids, terpenes, saponins and tannins. From the results, it can be concluded that M. parviflora has significant bioactivity against tested microorganisms and can be utilized in drug development against respiratory ailments
\end{abstract}

KEYWORDS: Agar well diffusion method, antibacterial activity, crude extracts, Malva parviflora, respiratory tract pathogens

\section{INTRODUCTION}

Numerous microorganisms are commonly associated with aerosols entered into the respiratory system with air and may be a major factor for infections. Microbes can harbour into oropharynx, nasopharynx and nasal cavity, causing sore throat and nasal discharges, in larynx, causing hoarseness, the middle ear, causing otitis media with earache, causing sinusitis with pain in the face or head, and the eyes, causing conjunctivitis or keratitis [1]. Upper respiratory tract is the chief reservoir of opportunistic/commensals bacteria including Streptococcus pneumoniae, Staphylococcus aureus, Haemophilus influenzae, Moraxella catarrhalis and Pseudomonas aeruginosa $[2,3]$. H. influenzae and M. catarrhalis are also responsible equally for Community Acquired Pneumonia (CAP) in lower respiratory tract. Some atypical pathogens i.e. Chlamydia pneumoniae, Mycoplasma pneumoniae and Legionella pneumophila are apparently present in CAP [4]. Even respiratory viruses including adenovirus, respiratory syncytial virus, influenza virus, human coronavirus and human rhinovirus are recently reported in clinical observation under respiratory infections [5].

Bacteria are capable of causing serious diseases becoming resistant to common antibiotics. The presence of phytochemicals is found in plants those played a major role in disease control as well as in enhancement of human health also. Investigations suggest that phenols, polyphenols, quinine, flavanones, flavonoids, tannins, coumarins, terpenoids, glycosides and saponins are few examples of such phytochemicals which act as antimicrobial, antidiarrhoeal, anthemintic etc. [6-10].

Malva genus is widespread in tropical and temperate region belongs to the family Malvaceae. They possess efficient role in coughing, intestinal infections, colitis, tonsillitis, gastroenteritis, cholesterol and lipid-lowering, antihypertensive, antioxidant, analgestics, emollient, pectoral girdle and arteriosclerosis treatment [11]. Malva parviflora Linn. is widely distributed in Uttarakhand. It is originated from the Mediterranean region of Europe and temperate Asia. Halvorson and Guertin [12] has been reported its medicinal uses and as food in many cultures since 6000 B.C. It prefers to grow in shade or slightly sunny area. It is an annual herb, commonly known as cheeseweed [13], marshmallow or little mallow with 40 to $60 \mathrm{~cm}$ in height. Flowers are white in colour. Plants of this family are distinguished for their antibacterial and antifungal activities due to the incidence of alkaloids, essential oils and phenolic quleoside $[14,15]$. It contains wide range of cytokines which are valuable in treatment of inflammation [16] and aerial parts with high concentration of proteins [17]. M. parviflora root

Copyright: $\odot 2018$ The authors. This article is open access and licensed under the terms of the Creative Commons Attribution License (http://creativecommons.org/licenses/by/4.0/) which permits unrestricted, use, distribution and reproduction in any medium, or format for any purpose, even commercially provided the work is properly cited. Attribution - You must give appropriate credit, provide a link to the license, and indicate if changes were made. 
extracts is used for the treatment of dysentery [18], leaves and seeds extracts for teeth infections, as laxative, expectorant and antitussive and in combination with Eucalyptus leaves, it helpful in coughing and other chest ailments $[19,20]$.

The literature survey showed very limited reports describing the antibacterial role of $M$. parviflora. Therefore, herein we demonstrate, antibacterial screening of crude extracts of $M$. parviflora were tested against selected respiratory tract pathogens.

\section{MATERIALS AND METHODS}

\section{Plant Material}

Fruits of M. parviflora were collected from Divya nursery, Patanjali Yogpeeth, Haridwar. Plant was identified at Botanical Survey of India (BSI), Dehradun and deposited a herbarium voucher specimen (BSD 113406). Fruits were cleaned in running water, dried out at room temperature and crushed in an electric grinder.

\section{Preparation of Extracts}

The fruit extracts were prepared with petroleum ether (PET), acetone (ACE), methanol (MeOH) and aqueous $\left(\mathrm{H}_{2} \mathrm{O}\right)$ by following standard method [21] and as explained previously [33].

\section{Microorganisms Used}

The bacterial strains namely Haemophilus influenzae (MTCC 3826), Pseudomonas aeruginosa (MTCC 2474), Staphylococcus aureus (MTCC 1144), Streptococcus pyogenes (MTCC 422) and Streptococcus pneumoniae (MTCC 655) were purchased from Institute of Microbial Technology (IMTECH), Chandigarh and maintained at $4^{\circ} \mathrm{C}$ on nutrient agar medium. For experiments, active bacterial cultures were prepared by transferring a loopful of cells from stock cultures to test tubes of Mueller Hinton Broth (MHB) and incubated without shakeup for $24 \mathrm{~h}$ at $37^{\circ} \mathrm{C}$.

\section{Antibacterial Testing}

The antibacterial activity was determined by standard method [21].

\section{Determination of Minimum Inhibitory Concentrations (MICs)}

Two-fold serial dilution method [22] was employed to evaluate the minimum inhibitory concentration (MIC).

\section{Phytochemical Screening}

The phytochemical analysis of plant extracts was done by following the method of Evans [23] and Scalbert [24].

\section{RESULTS AND DISCUSSION}

M. parviflora showed moderate antibacterial properties against selected microorganisms (Table 1). The MeOH extract of
M. parviflora was found most active against all selected bacterial pathogens followed by $\mathrm{H}_{2} \mathrm{O}, \mathrm{ACE}$ and PET. The maximum inhibition was found against S. pneumoniae $(20.6 \pm 0.57 \mathrm{~mm})$ and lowest against $P$. aeruginosa $(15.3 \pm 0.28 \mathrm{~mm})$ respectively. The moderate antibacterial activity was noted against S. aureus $(16.6 \pm 0.57 \mathrm{~mm}), S$. pyogenes $(16.6 \pm 0.28 \mathrm{~mm})$ and H. influenzae $(16.0 \pm 0.50 \mathrm{~mm})$. These findings can be justified with its medicinal uses reported by other researchers. According to Islam et al. [25] (2007-2010) hexane, chloroform $\left(\mathrm{CHCl}_{3}\right)$ and ethanol (EtOH) extracts of $M$. parviflora displayed activity against four bacteria i.e. B. subtilis, E. coli, S. aureus and P. vulgaris. EtOH extract of leaves and seeds showed activity against B. Subtilis, K. pneumoniae, S. aureus, E. aerogenes and $P$. aeruginosa [26]. The ethanol extract of $M$. parviflora leaves had been reported a significant neuroprotective effect as by decreasing in escape latency (EL) and significant increase in time spent in the target quadrant (TSTQ), kind of improvement of learning and memory in mice [27].

In another study, three antimicrobial proteins i.e. CW-3, CW-4 and CW-5 were purified from seeds of M. parviflora. CW-3 and CW-4 proteins showed activity against Phytopthora infestans [28]. Some study supports $M$. parviflora as a good source for synthesis of nanomedicine [29].

The sensitivity of tested bacterial strains was quite interesting in respect to reference drug (erythromycin). In comparison to erythromycin, the activity of $M$. parviflora fruit extracts was found less efficient. Erythromycin is a macrolide antibiotic with broad spectrum antimicrobial role. In case of respiratory tract infections, it has better treatment of microorganisms especially for atypical organisms i.e. Mycoplasma and legionellosis [30].

The MICs were calculated for MeOH extract (Figure 1) and found to be varied at $3.12-12.5 \mathrm{mg} / \mathrm{ml}$. The minimum inhibition was observed against S. pneumoniae at $3.12 \mathrm{mg} / \mathrm{ml}$ and maximum against $P$. aeruginosa at $12.5 \mathrm{mg} / \mathrm{ml}$ respectively. H. influenzae, S. aureus and S. pyogenes showed similar MICs at $6.25 \mathrm{mg} / \mathrm{ml}$.

The preliminary phytochemical analysis for $M$. parviflora fruit extracts showed the presence of alkaloids, flavonoids, glycosides, steroids, terpenes, saponins and tannins in $\mathrm{MeOH}$ extract, alkaloids and flavonoids in PET extract, alkaloids, flavonoids, steroids, terpenes and saponins in ACE extract, and flavonoids, steroids, terpenes, saponins and tannins in $\mathrm{H}_{2} \mathrm{O}$ extract (Table 2). The results can be justified with other co-workers finding which concluded the presence of major secondary metabolites including flavonoids, alkaloids, glucosides, tannins, saponins in various parts of M. parviflora.

Farhan et al. [31] had showed the presence of flavonoids, tannins, phenols, saponins, alkaloids and resin in stem and leaves of M. parviflora. Abdel-Ghani et al. [11] had reported seven compounds including $\beta$ - amyrin, $\alpha$-amyrin, a mixture of $\beta$ sitosterol and stigmasterol, cholesterol, campasterol, ergosterol, and $\beta$ - sitosterol-O- $\beta$-D-glucoside in petroleum fraction, ethyl vanillin in chloroform fraction and tribuloside, a flavonoid glycoside, in ethyl acetate fraction. If we focus on the 
Table 1: Antibacterial activity of Malva parviflora

\begin{tabular}{|c|c|c|c|c|c|c|}
\hline \multirow[t]{2}{*}{ Microorganisms } & \multicolumn{4}{|c|}{ *Diameters of inhibition zone $(\mathrm{mm})$} & \multirow[t]{2}{*}{ DMSO } & \multirow{2}{*}{$\begin{array}{l}\text { Positive Control } \\
\text { (Erythromycin) }\end{array}$} \\
\hline & PET & ACE & $\mathrm{MeOH}$ & $\mathrm{H} 2 \mathrm{O}$ & & \\
\hline H. influenzae & $8.3 \pm 0.28$ & $12.3 \pm 0.28$ & $16.0 \pm 0.50$ & $11.3 \pm 0.28$ & - & $21.3 \pm 0.76$ \\
\hline P. aeruginosa & $9.3 \pm 0.28$ & $11.3 \pm 0.28$ & $15.3 \pm 0.28$ & $12.3 \pm 0.07$ & - & $16.6 \pm 0.76$ \\
\hline S. aureus & $9.0 \pm 0.50$ & $11.6 \pm 0.28$ & $16.6 \pm 0.57$ & $13.2 \pm 0.12$ & - & $30.3 \pm 0.76$ \\
\hline S. pneumoniae & $9.6 \pm 0.28$ & $14.0 \pm 0.50$ & $20.6 \pm 0.57$ & $15.8 \pm 0.10$ & - & $19.3 \pm 0.57$ \\
\hline S. pyogenes & $9.0 \pm 0.50$ & $13.3 \pm 0.76$ & $16.6 \pm 0.28$ & $13.4 \pm 0.10$ & - & $25.6 \pm 0.28$ \\
\hline
\end{tabular}

*Values are mean \pm SE, - : No inhibition, Cork borer diameter: 6 mm, PET: Petroleum ether, ACE: Acetone, MeOH: Methanol, H20: aqueous,

DMOS: Dimethyl sulfoxide

Table 2: Screening of phytochemical from M. parviflora

\begin{tabular}{llcccc}
\hline S. No. & Phytoconstituents & \multicolumn{4}{c}{ Solvents } \\
\cline { 3 - 6 } & & PET & ACE & MeOH & H20 \\
\hline 1. & Alkaloids & + & + & + & - \\
2. & Flavonoids & + & + & + & + \\
3. & Glycosides & - & - & + & - \\
4. & Steroids & - & + & + & + \\
5. & Terpenes & - & + & + & + \\
6. & Saponins & - & + & + & + \\
7. & Tannins & - & - & + & + \\
\hline
\end{tabular}

+ : Present, - : Absent, PET: Petroleum ether, ACE: Acetone, $\mathrm{MeOH}$ : Methanol, $\mathrm{H} 2 \mathrm{O}$ : aqueous

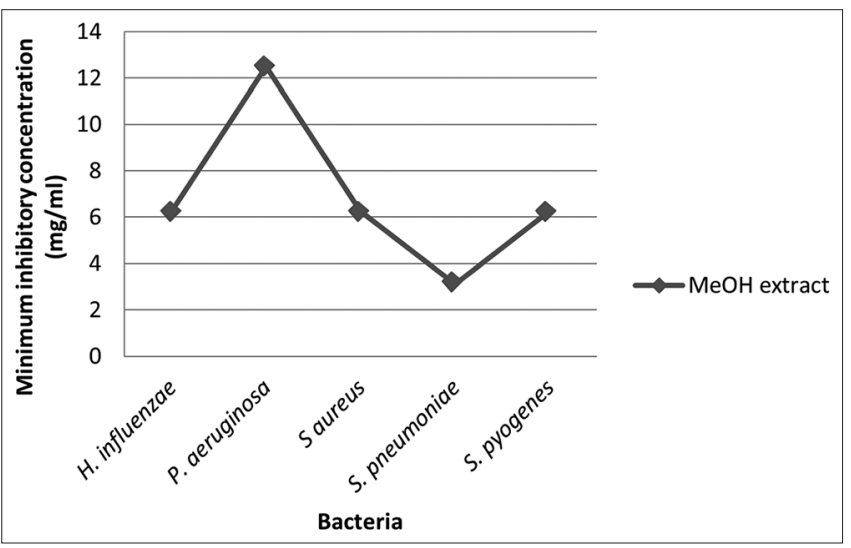

Figure 1: Minimum Inhibitory Concentrations (MICs) of $\mathrm{MeOH}$ extract of $M$. parviflora. The inhibition is noted at (a) $6.25 \mathrm{mg} / \mathrm{ml}$ against $H$. influenzae, S. aureus and S. pyogenes (b) $12.5 \mathrm{mg} / \mathrm{ml}$ against $P$. aeruginosa (c) $3.12 \mathrm{mg} / \mathrm{ml}$ against $S$. pneumoniae

biological properties of these phytoconstituents, a wide range of activity can be observed. Phytochemicals are responsible for colour, odour etc. and bearing protective or disease preventive properties. They are accountable for some other properties including antioxidant activity, hormonal action, enzymatic activity, interference with DNA replication, antimicrobial activity etc. [32].

\section{CONCLUSION}

In conclusion, M. parviflora fruit extracts have moderate antibacterial properties against selected microorganisms. The bioactivity of fruit extracts was confirmed by the results of phytochemical analysis. This can be utilized in respiratory tract illnesses caused by studied microorganisms. Further, research should be carried out to explore the bioactive components of M. parviflora.

\section{CONFLICT OF INTEREST}

The authors declare that they have no conflict of interests.

\section{ACKNOWLEDGEMENTS}

The authors are thankful to the Head, Department of Botany and Microbiology, Gurukul Kangri University, Haridwar for providing the laboratory facilities to pursue this research work and Botanical Survey of India (BSI), Dehradun for plant identification.

\section{REFERENCES}

1. Collee JG, Duguid JP, Fraser AG, Marmion BP, Simmons A. Laboratory strategy in the diagnosis of infective syndromes. In: Mackie \& McCartney Practical Medical Microbiology, Collee JG, Marmion BP, Fraser AG, Simmons A, editors. 1996; pp 56-64. ISBN:044-304-9068

2. Brook I. Microbiology of sinusitis. Proc. Am. Thorac. Soc. 2011:8(1):90-100. doi:10.1513/pats.201006-038RN

3. Bosch AATM, Biesbroek G, Trzcinski K, Sanders EAM, Bogaert D. Viral and bacterial interactions in the upper respiratory tract. PLoS Pathog. 2013;9(1):e1003057. doi:10.1371/journal.ppat.1003057

4. Guthrie R. Community acquired lower respiratory tract infections: etiology and treatment. Chest 2001;120(6):2021-2034. doi:10.1378/ chest.120.6.2021

5. Ryu S, Kim S, Kim BI, Klein EY, Yoon YK, Chun BC. Temporal relationship between antibiotic use and respiratory virus activities in the republic of Korea: A time-series analysis. Antimicrobial Resistance \& Infection Control. 2018;7:56. doi: 10.1186/s13756-018-0347-8

6. Cowan MM. Plant products as antimicrobial agents. Clinical Microbiology Review. 1999;12(4):564-582.

7. Mali RG, Mahajan SG, Mehra AA. In vitro anthelmintic activity of stem bark of Mimusops elengi Linn. Pharmacognosy magazine. 2007:3(10):73-76.

8. Wang GS, Han J, Zhao LW, Jiang DX, Liu YT, Liu XL. Anthelmintic activity of steroidal saponins from Paris polyphylla. Phytomedicine 2010;17:1102-1105.

9. Shaibani TRMA, Phulan MS, Shiekh M. Anthemintic activity of Fumaria parviflora (Fumariaceae) against gastrointestinal nematodes of sheep. Int. J. Agric. Biol. 2009;11:431-436.

10. Bachaya HA, Iqbal Z, Khan MN, Jabbar A, Gilani AH, Din IU. In vitro and in vivo anthelmintic activity of Terminalia arjuna bark. Int. J. Agric. Biol. 2009; 11:273-278.

11. Abdel-Ghani AE, Hassan HM, El-Shazly AM. Phytochemical and biological study of Malva parviflora L. Grown in Egypt. Zagazig. J. Pharm. Sci. 2013;22(1):17-25

12. Halvorson WL, Guertin P. Factsheet for: Malva parviflora L. USGS weeds in the west project: Status of introduced plants in Southern Arizona Parks, 2003.

13. Wang $X$, Bunkers GJ. Potent heterologous antifungal proteins from cheeseweed (Malva parviflora). Biochem. Biophys. Res. Commun. 
2000;279(2):669-673. doi:10.1006/bbrc.2000.3997

14. Ndunga M, Oumba JM. Antimicribial and antifungal activities of essential oils of Ocimum grattisimum and Ocimum basilicum from Congo. Fitotherapia 1997;97(2):190-191.

15. Abad MJ, Ansuategui M, Bermejo P. Active antifungal substances from natural sources. Arkivoc. 2007;2:116-145.

16. Shale TL, Stirk WA, Staden JV. Variation in antibacterial and anti-inflammatory activity of different growth forms of Malva parviflora and evidence for synergism of the anti-inflammatory compounds. J. Ethnopharmacol. 2005;96(1-2):325-330. doi:10.1016/j. jep.2004.09.032

17. Ereifej KI, Feng H, Rababah T, Almajwal A, Datt MA, Gammoh SI, Oweis LI. Chemical composition, phenolics, anthocyanins concentration and antioxidants activity of ten wild edible plants. Food and Nutrition Sciences. 2015;6:581-590. doi:10.4236/fns.2015.67061

18. Hernandez T, Canales M, Avila JG, Duran A, Caballero J, Vivar ARD, Lira R. Ethnobotany and antibacterial activity of some plants used in traditional medicine of Zapotitlan de las Salinas, Puebla (Mexico). J. Ethnopharmacol. 2003;88:181-188. doi:10.1016/S03788741(03)00213-7

19. Nimri LF, Meqdam MM, Alkofahi A. Antibacterial activity of Jordanian medicinal plants. Pharm. Biol. 1999;37:196-201.

20. Akbar S, Hanif U, Ali J, Ishtiaq S. Pharmacognostic studies of stem, roots and leaves of Malva parviflora L. Asian Pacific Journal of Tropical Biomedicine. 2014;4(5):410-415. doi:10.12980/APJTB.4.2014C1107

21. Ahmad I, Mehmood Z, Mohammad F. Screening of some Indian medicinal plants for their antimicrobial properties. J. Ethnopharmacol. 1998;62:183-193.

22. Aboaba OO, Smith SI, Olude FO. Antibacterial effect of edible plant extract on Escherichia coli 0157:H7. Pakistan Journal of Nutrition. 2006;5(4):325-327.

23. Evans WC. Trease and Evans Pharmacognosy, $5^{\text {th }}$ ed. India: Harcourt Brace and Company; 1996.

24. Scalbert A. Antimicrobial properties of tannins. Phytochemistry $1991 ; 30: 3875-3883$

25. Islam M, Ali E, Saeed MA, Jamshaid M, Khan MTJ (2007-2010).
Antimicrobial and irritant activities of the extracts of Malva parviflora L., Malvastrum coromandelianum L., and Amaranthus viridis L.- a preliminary investigation. Pakistan Journal of Pharmacy. 2007-2010;20-23(1\&2):3-6.

26. Miri A, Rad JS, Alfatemi SMH, Rad MS. A study of antibacterial potentiality of some extracts against multidrug resistant human pathogens. Annals of Biological Research 2013;4(8):35-41.

27. Aslam M, Sial AA. Neuroprotective effect of ethanol extract of leaves of Malva parviflora against Amyloid- $\beta-(A \beta)$ mediated Alzheimer's disease. International Scholarly Research Notices. 2014; doi: $10.1155 / 2014 / 156976$

28. Wang X, Bunkers GJ, Walters MR, Thoma RS. Purification and characterization of three antifungal proteins from cheeseweed (Malva parviflora). Biochem. Biophys. Res. Commun. 2001;282(5):1224-1228. doi: 10.1006/bbrc.2001.4716

29. Zayed MF, Eisa WH, Shabaka AA. Malva parviflora extract assisted green synthesis of silver nanoparticles. Spectrochim. Acta Mol. Biomol. Spectrosc. Spectrochim. Acta. Mol. Biomol. Spectrosc. 2012;98:423-428. doi:10.1016/j.saa.2012.08.072

30. Kwon JH. Macrolides, ketolides, lincosamides and streptogramins. In: Cohen J, Powderly WG, Opal SM, editors. Infectious Disease, $4^{\text {th }}$ ed. 2017;pp 1217-1229.e1, doi: 10.1016/B978-0-7020-62858.00141-6

31. Farhan H, Rammal H, Hijazi A, Hamad H, Daher A, Reda M, Badran B. In vitro antioxidant activity of ethanolic and aqueous extracts from crude Malva parviflora L. Grown in Leanon. Asian J. Pharm. Clin. Res. 2012;5(3):234-238.

32. Doughari JH. Phytochemicals: Extraction methods, basic structures and mode of action as potential chemotherapeutic agents. In: Phytochemicals- A Global Perspective of their Role in Nutrition and Health, Venketeshwer Rao editor. 2012; p. 1-33. ISBN: 978-953-510296-0

33. Gautam SS, Navneet Kumar S. Appraisal of antimicrobial properties of Onosma bracteatum Wall. fruit extracts against respiratory tract pathogens. Journal of Medicinal Herbs and Ethnomedicine. 2015; $1: 108-112$. 